\title{
„Restricted Codes” w teorii Basila Bernsteina \\ a poczucie społecznego resentymentu (perspektywa światłej edukacji przeciwstawiana ślepocie i bierności publicznej)
}

\begin{abstract}
Streszczenie: Uwagi autora skupiają się i związane są z niektórymi fundamentalnymi zmianami społeczno-politycznymi ostatniego okresu w Polsce. Oddziaływanie prasy i innej medialnej agitacji, a także wypowiadanie wielu opinii skierowanych do mniej wyedukowanej części społeczeństwa polskiego ( 44\%) przez reprezentantów partii rzadzacej „Prawo i Sprawiedliwość”, przywołuje w ludzkiej świadomości emocjonalne społeczne poczucie resentymentu. Jest to proces społecznego odbioru wielu przekazów medialnych w kategoriach kampanijnej agitacji (strategii interwencyjnych) na osi continuum: osobowość - percepcja - emocje - podatność - tradycja - wybór polityczny. W artykule zawarto fragmenty Basila Bernsteina socjolingwistycznej teorii na temat języka i jego wpływu na postrzeganie przez individuum rzeczywistości.
\end{abstract}

Słowa kluczowe: teoria Basila Bernsteina, kody otwarte i ograniczone, język przekazu, resentyment publiczny, polityczne emocje

\section{Uwagi wprowadzające}

Niektóre kwestie (zagadnienia, jak i ich wątki) występujące w znakomitej teorii socjolingwistycznej opracowanej przez Basila Bernsteina (1924-2000) można rozpatrywać z różnych punktów widzenia. W niniejszym opracowaniu postaram się przedstawić niektóre elementy moich rozważań - sądzę, że przydatne szerokiej rzeszy odpowiedzialnych reprezentantów współczesnej edukacji - w intencji zbiorowego (przynajmniej większości) przeciwstawiania się nadzwyczaj sprawczej logice ich stosowania przez obecnie sprawujących jakże niepokojąco od blisko sześciu już lat komunitarystyczną władzę. Mam na myśli język publicznego przekazu i jego specyficzną frazeologię stylową bądź to leksykalną, którą Katarzyna Kłosińska wraz z Michałem Rusinkiem określają jako nagminne przytaczanie szeregu wyrazów o obraźliwym i często 
wulgarnym, a nie tylko ludycznym - jak to dotychczas postrzegałem - odcieniu. Owo dobrozmianowe słownictwo polega na krzewieniu nowej i wręcz nieprawdziwej rzeczywistości, internalizującej określone normy i wartości poprzez przyswojenie szczególnego rodzaju percepcji przez słuchaczy odgrywających rolę respondentów w manipulowaniu eksperymentem publicznym działaczy PiS i ich dzisiejszych sympatyków. Tego rodzaju oddziaływania trafiają niestety do szerokich rzesz ludności o tradycyjnych przekonaniach, niewysokim stopniu wiedzy ogólnej. $Z$ wysokim prawdopodobieństwem orzec można, iż są to warstwy legitymujące się w zdecydowanej większości zaledwie podstawowym, zawodowym lub też niepełnym ich wykształceniem na omawianym poziomie. Ów odsetek na tle innych państw UE jest bardzo wysoki ( 45\%) ogółu. Oczywistą jest prawdą, że [...] granice między światem, który istnieje, a światem pożądanym, tworzonym przez język, się zacierają. Dzieje się tak nie tylko za sprawą posługiwania się swoistym słownictwem, lecz także dzięki temu, w jaki sposób się go używa - jest ono wpisane w rytuał, a więc powtarzalne i przewidywalne. A jeśli jest powtarzalne i przewidywalne, to odbiorca może odnieść wrażenie, że jest to jedyny możliwy język. Skoro tak - to świat przezeń oddawany jest jedynym możliwym światem.

Wobec tego - jaki to jest świat? Jak wygląda świat kreowany przez język $\gg$ dobrej zmiany «? Przede wszystkim jest to świat podzielony bez reszty, zgodnie z logiką retorycznej figury antytezy - jest się albo patriota, albo zdrajca, targowica, mordami zdradzieckimi, ubekami, postkomunistami; tertium non datur. »Ciemna strona « tej antytezy jest zwykle hiperbolizowana: to bojów$k i$, totalna opozycja, tajemnicze i amorficzne sity, nieokreślone elity i niejasne afery. »Jasna strona « rządzi się figurą synekdochy: skoro krytyka PiS-u to atak na Polskę, plucie na Polskę i zdrada, to znaczy, że PiS to Polska. Jest to świat wartości zagrożonych - przez multikulti, uchodźców, postępaków, lewaków, LGBT, Niemców, elity czy tych, którzy chcą wprowadzić seksualizację dzieci. Dominującymi emocjami w tym świecie są duma (żołnierze wyklęci, patriota, pedagogika dumy, bijące serce Europy, wstawać z kolan, polska gospodarka, suweren) oraz strach przed tym, że się tej dumy zostanie pozbawionym (pedagogika wstydu, poprawność polityczna, postkomunizm, ubecy) ${ }^{1}$.

1 Ministerstwo/Urząd Bezpieczeństwa Publicznego (potocznie określony skrótem UB) utworzono w czasie wprowadzania dyktatury komunistycznej PRL, powstał w 1945 roku. Został zlikwidowany 9 lat później (1954). Odpowiedzialny był on za masowe i krwawe represje, głównie w okresie stalinizmu. Pracowników UB w języku potocznym pogardliwie określono pojęciem „ubek”. Po dzień dzisiejszy w świadomości społecznej funkcjonuje głęboko negatywny wizerunek owej spośród 24 tys. zatrud- 
Jest to świat nieustannej walki, trwania w gotowości do obrony godności oraz wartości, które uznaje się za kwintesencję polskości (życie, rodzina). W świecie tym nie ma przeciwników - są wrogowie, bo miejsce retoryki sportowej, w której są przeciwnicy, drużyny i rozgrywki (czyli retoryki charakterystycznej raczej dla polityków liberalnych), zajmuje retoryka militarna. Wrogowie zasługują na potępienie i wykluczenie, a to, co im bliskie, jest unieważniane - jak mówił Jarosław Kaczyński kilka dni przed wyborami parlamentarnymi w październiku 2019 roku: „Nowa polska elita władzy i, mam nadzieję, coraz większa część elity kulturowej i innych elit już nie pracuje dla naszych wrogów. A ci, którzy pracują, są napiętnowani. I będą, proszę państwa, piętnowani dalej"2 (Kłosińska i Rusinek, 2020, ss. 6-8).

Sygnalizowane powyżej rysy sprawowanej obecnie władzy, tj. pomijanie współdziałania z ludźmi o odmiennych doświadczeniach i spojrzeniu, nawet tym ekspertalnym, to nie tylko łamanie obowiązujących prawideł, ale także z rzadka w dobie współczesnej rozwiniętych postindustrialnych państw świata wyrażana niekompetencja i przejawiana publicznie buta, a z pewnością niegodziwość moralna (por. Murawski, 1989, s. 67, Sztompka, 1997, s. 8-15; Radziewicz-Winnicki, 2017, s. 9-23). Siła, potencjalizacja przemocy - chociażby zaledwie symbolicznej, lęk, strach, poczucie traumy itp. stanowić mogą dla reprezentantów nauk społecznych zaczątek mobilności publicznej, a przy tym bardziej skuteczne niż dotychczasowe ruchy przełamywania i pokonywania oporu stawianego przez laików i niekompetentnych nominatów partyjnych. Oczywistym celem pozostaje w uporczywej eksperckiej batalii wyborczej wyrugowanie z życia publicznego tych na co dzień wszel-

nionych stereotypowej postaci szerzącej grabieże, mordy, wywołującej ból, płacz i powszechną traumę. Część powojennych uprawnień w 1956 roku przyjęła Służba Bezpieczeństwa (SB), tj. organ będący częścią struktury Ministerstwa Spraw Wewnętrznych, nota bene rozwiązany w końcu 1990 roku. Ich pracowników określano w przestrzeni publicznej mianem $S B$-ków. W prawie wszystkich wystąpieniach, które określamy jako propagandowo-rozliczeniowe, działacze PiS utożsamiają pracowników organu z pierwotnie przyjętą z okresu stalinowskiego nomenklaturą ubecką. Co więcej, także przyrównania uproszczone i zabarwione emocjonalną treścią (na osi continuum przybierają dychotomiczną postać: swój - obcy; ubek zamiennie utożsamiany jest często z członkostwem w PZPR.

2 Wypowiedź J. Kaczyńskiego z 8 X 2019. Zob. J. Sobieniowski, Jakie elity chce "piętnować" prezes PiS Jarosław Kaczyński?, Fakty, TVN, 10 X 2019, https://fakty. tvn24.pl/ogladaj-online,60/jaroslaw-kaczynski-chce-pietnowac-elity-o-kim-mowil976329.html; Przytacza: Kłosińska i Rusinek, 2020, s. 8. 
kich chorobliwych, psychopatycznych postaw, egzemplifikowanych nabytych w przeróżny sposób aktów woli, romantycznych utopijnych złudzeń, i behawioralnego nastawienia, dodajmy, wrogiego, do innych osób stanowiących przeszkody - dziś nie do pokonania - w normalnej oczekiwanej ewolucji rozwoju europejskiego państwa (Sztompka, 1994, ss. 14-16; Murawski, 1989, ss. 65-67; Radziewicz-Winnicki, 1998, ss. 46-47; Bielska, 2013). Sprawowanie władzy może być zatem - i staje się także w moim rozumieniu - podążając interpretacją arystotelowską, korelacją zawsze polityki z etyką, w myśl której władza sprawowana jest dla dobra zarówno rządzących, jak i rządzonych, a wszystkie inne odstępstwa, chociażby nawet niezbyt liczne przypadki odbiegające od tej nieomal tautologicznej zasady/reguły postępowania w cywilizowanym świecie, traktowane muszą być jako przejaw patologii, a wręcz przestępstwa. Winny być one napiętnowane oraz bezwzględnie i przykładnie karane (Murawski, 1989, ss. 67-68).

W prowadzonych analizach będę się starał skupiać wyłącznie na naukowym wyjaśnieniu obecnej sytuacji polityczno-społecznej i na stałej (od końca 2015 roku) osobliwej propagandzie partyjno-rządowej. Ostateczna operacjonalizacja niektórych pojęć pozwala na eksponowanie pewnych słowotwórczych elementów stosowanego kodu językowego w publicznym przekazie jako szczególnie odpowiedzialny przedmiot naszych zainteresowań i jako próba ogarnięcia przez badacza szerszej klasy występującego zjawiska, na które składa się wiele procesów. Z pewnością uwidacznia się rola nabytych uprzednio sądów spostrzeżeniowych wpływających na obecną interpretację zastanej w kraju narodowej wspótczesności. W poprzednich tekstach, doby dekadencji, jak to określam, cieszących się zresztą dużym zainteresowaniem reprezentantów nie tylko pedagogiki czy socjologii, analizowałem wiarę szeregu przedstawicieli $\mathrm{PiS}$ w komunitaryzm, a de facto niezbyt spójne ramy tej (tychże) teorii, czy zaledwie zarysowanych koncepcji. Przywoływałem wówczas popularną w niektórych kręgach zachodnich filozofów, politologów, socjologów utopijne raczej teorie sprawiedliwości społecznej, głównie Johna Rawlsa, które starałem się poddać zwięzłej rekapitulacji. Miałem na myśli odwoływanie się w ramach istniejącej już umowy społecznej do zasady justice as fairness ${ }^{3}$, a zwłaszcza kiedy będą istniejące nierówności wyrówna-

3 W zasygnalizowanych teoriach, podział dóbr winien być zawsze sprawiedliwy (just - z angl.), a może on nim pozostawać tylko wówczas, jeżeli jest bezstronny, przejrzysty (fair - z angl.); czyli wówczas, kiedy ofiaruje on każdemu takie same wręcz identyczne możliwości w zakresie partycypacji społecznej. 
ne/kompensowane z największym udziałem/korzyścią dla najbardziej upośledzonych (Radziewicz-Winnicki, 2017, ss. 13-18). Powiązanie wybranych elementów teorii Bernsteina z realiami kulturowymi, mentalnymi i społeczno-politycznymi - na przykładzie socjolingwistycznego oblicza współczesnej Rzeczypospolitej, stanowić może odzwierciedlenie sprawczego wzmocnienia uprzedniej wytworzonej wiary (resentymentu) jednostki, a przy tym intencjonalnego zabiegu socjotechnicznego polityków wiodącej partii aktualnie sprawującej władzę. To wyraźna (jedna z dwóch cech), o których wspomina Margaret Archer, które to pozwalają nam uświadomić, że teorie dotyczące relacji między strukturami a przedmiotami działania społecznego (social agents) oraz między kulturami a aktorami kulturowymi (cultural actors) winny uwzględniać relatywną autonomię zarówno struktury publicznej, jak i samej kultury zawartej w mentalnej emancypacji narodu. W przeciwnym wypadku nie potrafilibyśmy zrozumieć otaczającego nas życia społecznego jako wzajemnego oddziaływania zarówno interesów, jak i głoszonych nagminnie idei (Archer, 2019, s. 73). Owa zwięźle sformułowana myśl filozoficzno-socjologiczna (maksyma) o zabarwieniu etycznym, wypowiedziana przez uczoną o uznanym obywatelstwie międzynarodowym w świecie nauki i niebywałej sławie, zdecydowała ostatecznie o moich analizach poprzedzających ostateczną wersję przedłożonego do druku niniejszego artykułu. Będę próbował udowodnić (poprzez wyjaśnienie, naświetlenie, wypowiedzi ekspertów bądź interpretację innych autorów), że pomijanie przekazu informacji w omawianym zakresie (pedagogom praktykom, czy też bardziej teoretyzującym) nauczycielom akademickim, stanowi poważną lukę, a wręcz uchybienie. Namawiam do prowadzenia dalszych eksplikacji w tym zakresie, i oby były one skierowane ku politykom społecznym po to m.in., by zainteresować wszystkich złudnymi oddziaływaniami propagandowo-socjalizacyjno-wychowawczymi. Wierzę, że tylko wówczas w trakcie prowadzenia tej naukowej debaty publicznej (a nie agitacyjnej kampanii) skierować będzie można do wszystkich zainteresowanych po części już zweryfikowane i propagowane rozstrzygnięcia praktyczne powstrzymujące złudne i prymitywne formuły intensywnego krzewienia specyficznej i prymitywnej percepcji współczesnego świata, a także nieokiełznanego nacisku/wpływu społecznego przez jakiekolwiek ugrupowanie partyjne. Poszerzamy tym samym wiedzę na temat racjonalizacji oddziaływań zbiorowych przez naukę w przekazie, nieco popularnym, trudnej przecież publicystyki naukowej. 


\section{Elementy zapisu Bernsteina w masowym i publicznym przekazie}

Basil Bernstein początkowo był znany w Anglii jako autor wielu prac z zakresu socjolingwistyki. W 1962 roku w Uniwersytecie Londyńskim, w ramach wewnętrznej struktury Institute of Education, utworzono specjalną grupę pracowników (Sociological Research Unit) zajmujących się wyłącznie badaniami socjopedagogicznymi, poświęconymi szeroko rozumianym zagadnieniom nauczania, kształcenia i wychowania. Grupie tej przewodniczył sam Bernstein. W 1967 roku uzyskał profesurę, a jego zespół badawczy stanowił trzon nowo powstałej katedry (Department of Sociology of Education), której kierownictwo Bernstein objął. Mimo wykształcenia socjologicznego przez wiele lat był zatrudniony w resorcie oświaty i wychowania. Prace teoretyczne profesora Bernsteina powstawały na styku socjologii pedagogii/ pedagogiki i socjolingwistyki. Było to niejako praktyczne przystosowanie socjologii do analiz procesów określonych jako oświatowo-wychowawczo-socjalizacyjnych (Szreter, 1980, ss. 295-297; Radziewicz-Winnicki, 1985, ss. 338-342).

W Anglii uznano tę działalność za niezmiernie istotne „przesunięcie akcentu" (shift of emphasis). Już w 1971 roku Albert H. Halsey pisał, iż prawdą jest, że większość dotychczasowej literatury z zakresu kształcenia i wychowania wcale bądź tylko w niewielkim stopniu interesowała się zawartością programów szkolnych czy też procesem określanym jako pedagogiczny. To właśnie on, Bernstein, odwrócił akcenty i to wszystko, co jest związane z nauczaniem i kształceniem, postawił w centrum uwagi (Halsey, 1971; Hopper, 1979; Radziewicz-Winnicki, 1984, ss. 12-25).

Jean Floud (1978) w pracy Functions, Purposes and Powers in Education stwierdzał stanowczo, że analizy socjolingwistyczne Bernsteina przyczyniły się również do zwiększenia naszej wyobraźni w zakresie problematyki stylu narracji i wzrostu autorytetu nauczyciela w klasie szkolnej, a także organizacji samego programu nauczania; właśnie dzięki niemu socjologowie wychowania znaleźni wreszcie drogę do badania procesów edukacyjnych (Bernstein, 1971, 1974, 1975; Fluod, 1978; Radziewicz-Winnicki i Walker, 1986, ss. 53-57; Bokszański i Piotrowski, 1990; Bielecka-Prus, 2020).

Na zakończenie pobieżnego przeglądu ocen zawartych w Uwagach wprowadzajacych warto przytoczyć m.in. trafne opinie Andrzeja Piotrowskiego oraz Zbigniewa Bokszańskiego, autorów obszernego wstępu do cytowanej 
uprzednio pracy Bernsteina, tłumaczonej na język polski. Zwracają oni uwagę, iż określenie teoretycznej tożsamości licznych propozycji Bernsteina nie jest łatwe. Nie podejmuje on metateoretycznych analiz, które pozwoliłyby na jednoznaczne umiejscowienie przyjętego przez siebie stanowiska. Nie rozwija także swoich schematów pojęciowych w kierunku określonym przez jedną tylko perspektywę teoretyczną. Rekonstrukcja splotów idei i perspektyw, które się przewijają w całej bogatej twórczości Bernsteina, jest bardzo trudna, w indywidualnej recepcji jej czytelników (Radziewicz-Winnicki, 1993, s. 13). Wymienieni autorzy trafnie zaznaczają, iż „[...] zamykająca pierwszy okres dociekań Bernsteina koncepcja dwóch systemów mowy spotkała się z krytyką ze strony lingwistów. Krytyka ta nie mogła jednak unieważnić faktu istnienia różnic kulturowych między członkami skrajnych pod względem cech położenia społecznego warstw społecznych. A różnice te stanowiły już wtedy podstawowy obiekt zainteresowań Bernsteina. Dalsza droga jego poszukiwań to próby znajdowania coraz bardziej konstytutywnych zasad struktur społecznych. Zasad odzwierciedlających się w różnicach kulturowych, w tym zwłaszcza w języku i kompetencjach komunikatywnych" (Piotrowski i Bokszański, 1990, s. 14).

Uogólniając całokształt dorobku autora, można powiedzieć, że Bernstein analizuje procesy edukacyjne przez pryzmat kryzysu kapitalizmu, w fazie/ formule systemu monopolistyczno-państwowego. Liczne konkluzje autora dowodzą, że zwiększenie się sprzecznych lokalizacji w strukturze klasowej, proletaryzacja klas, fiskalny kryzys państwa, wzrost interwencjonizmu państwowego oraz wyłonienie się dwóch klasowych relacji wewnątrz aparatu państwowego to okoliczności, które zmieniają charakter współczesnej oświaty, w tym także działań natury socjalizacyjno-wychowawczej, a w przypadku PiS-u, jak mniemam, zdecydowanie socjotechnicznej. Powstałe w poprzednim okresie historycznym systemy oświatowe dają początek nowemu cyklowi przemian. Pozornie - w opinii Bernsteina - oświata jest bardziej autonomiczna, sprofesjonalizowana. W jej obrębie dokonują się jednak określone zmiany wewnątrz pewnych typów interakcyjnych, wśród których najistotniejszy, zewnętrzny, dotyczy relacji między grupami nauczycielskimi a innymi grupami nacisku oraz politycznej manipulacji przez rządowe władze lokalne czy też centralny aparat państwowy. Zwalcza on przy tym nierzetelne i skrótowe przekazy językowe. Powszechnie podkreśla się rzadko spotykaną wśród humanistów dyscyplinę myślową autora występującą w danym konkretnym opracowaniu. Wywody są spójne, logiczne, o przejrzystej konstrukcji logicznej. Sam język przekazu jest jednak trudny w odbiorze, pozostając 
na bardzo wysokim poziomie abstrakcji. Kierunek interpretacji procesów rozwojowych oraz badań empirycznych w jego ujęciu jest nacechowany przede wszystkim działalnością profilaktyczno-kompensacyjną związaną z neutralizowaniem czynników środowiskowych powodujących potencjalne zagrożenie $^{4} w$ rozwoju dziecka. Dostrzegał on tu bowiem negatywną rolę ich działania, występującą we współczesnym zurbanizowanym społeczeństwie przemysłowym, a także postindustrialnym. Stymulowania określonej i właściwej sytuacji wychowawczej dopatruje się Bernstein między innymi w rozwoju mowy ludzkiej. Było to swoiste novum w socjopedagogicznej światowej literaturze przedmiotu sprzed półwiecza. Warto przyjrzeć się bliżej tej koncepcji, a w zasadzie zaledwie przypomnieć.

Bernstein bierze pod uwagę dwie podstawowe klasy istniejące w społeczeństwie brytyjskim, a mianowicie: klasę robotniczą (working class) oraz klasę średnią (middle class). Klasom tym przypisuje różny pod względem psychologicznym sposób zachowań, różne postawy, działania oraz powiązany z tym inny system mowy. Wytwarzające się w ich obrębie typy stosunku poznawczego do przedmiotów nie zależą wcale od indywidualnych cech wrodzonych jednostki, lecz stanowią wyłącznie funkcję procesów socjalizacyjno-wychowawczych.

Członkowie klasy średniej są w wysokim stopniu uwrażliwieni na całą strukturę przedmiotów i faktów z otaczającej ich rzeczywistości. Z reguły widzą i reagują na poszczególne wytwory materialne i symbole w całej sieci relacji z innymi rzeczami. Rozumieją zatem zależności przestrzenne, czasowe oraz przyczynowe między poszczególnymi zbiorami zdarzeń i zjawisk. Sposób wychowania dzieci w typowej dla tej klasy rodzinie jest z zasady racjonalny, a wszelkie oddziaływania wychowawcze są podporządkowane celom długofalowym. Stosuje się przy tym system kar i nagród jako stabilny, system wychowawczy wywołujący pożądane efekty. Dziecko ma od samego początku ściśle określony cel życiowy oraz wizję własnej kariery (ciągu wydarzeń, wizję oczekiwanego pełnienia w przyszłości określonych ról społecznych). Rozpatruje ono wówczas przedmioty ze swojego najbliższego otoczenia z punktu

4 W przeciwieństwie do uruchomienia na przestrzeni blisko sześciu już lat licznych emocji i postaw wśród potencjalnych wyborców PiS w stosunku do opozycji wskrzesza nadawca do użytku publicznego takie np. terminy jak: antypolski, antypolonizm, szkalowanie polskości polegające na dzieleniu w świadomości przeciętego obywatela (stygmatyzowanie, naznaczanie); które mają marginalizować, a wręcz wykluczać z narodowej wspólnoty tych określanych jako zdecydowanie wrogich $i$ gorszych obywateli tzw. drugiego sortu (por. Kłosińska i Rusinek, 2019, s. 24). 
widzenia osiągania wyznaczonych sobie celów. Zwiększa to spostrzegawczość i zainteresowanie wychowanka, wytwarzając jednocześnie świadomość uporządkowania ogólnego rzeczywistości i przyczyniając się do szybkiego przyswojenia wielu pojęć abstrakcyjnych.

Dziecko pochodzące ze środowiska robotniczego (rodziców legitymizujących się niższym wykształceniem) - twierdzi Bernstein - z reguły postrzega indywidualnie oderwane przedmioty ze swego najbliższego otoczenia. Nie tworzy ono związków przyczynowo-skutkowych między poszczególnymi obiektami czy też klasami zdarzeń. Decydującą i dominującą rolę w tym środowisku odgrywa teraźniejszość i zaspokojenie bieżących potrzeb jednostek. W zasadzie nie formułuje się celów długofalowych, niewiele wspomina się wychowankom o dalszej przyszłości. Stosowany w rodzinie system kar i nagród jest już znacznie mniej stabilny i konsekwentny. Poznawcze i emocjonalne postrzeganie świata okazuje się także znacznie uboższe i stereotypowo uproszczone (tak jak współczesna retoryka przekazu PiS-u - kursywa ARW). Dominują powszechnie niedopowiedzenia, brak precyzyjnych określeń, np. sformułowanie: Polska bijacym sercem Europy. Dziwna to metafora zdaniem cytowanych ekspertów. Przywołuje ona pytanie, czy inne kraje w ogóle żyją? Czy też pozostają one obumarłe? (Kłosińska i Rusinek, 2019, ss. 41-43).

Bernstein stawia w tym miejscu pytanie: W jaki sposób wytworzyły się różnice socjalizacyjno-kulturowe oraz wychowawcze tak jaskrawo przeciwstawne w obu środowiskach? Formułuje on także natychmiastową odpowiedź. Olbrzymi wpływ na to różnicowanie wywierają akty językowe transmisji (mowa ludzka) przekazujące doświadczenie i postawy rodziców, wpajających dzieciom wzory zachowań uznane przez nich za odpowiednie i właściwe (Bokszański i Ziółkowski, 1990, ss. 108-109).

Bernstein wielokrotnie powtarzał, iż nauki społeczne zarówno w przeszłości, jak i obecnie wykazywały niesłusznie wysoce lekceważący stosunek do badań nad mową człowieka. Na tym tle - omawiając liczne relacje zachodzące między formami mowy a formą istniejących relacji społecznych - udowadnia on, że fenomenem mowy jest jednym z najważniejszych aspektów kultury homo sapiens, jako bezpośredni środek przekazu wszelkich treści kulturowych (Bernstein, 1975, ss. 140-141).

Język ludzi traktuje ów autor jako szczególnie ważny nośnik genów społecznych. Niestety „[...] pomimo licznych badań, które pozwoliły dostrzec rolę języka w procesie formowania się odrębnego »ja« społecznego jednostki, nie ma współcześnie wśród prac poświęconych socjalizacji ani jednego empirycznego studium, w którym konsekwentnie badano by mowę jako proces pozwalają- 
cy dziecku uzyskać specyficzną tożsamość społeczną. Na temat wychowania dzieci napisano bardzo wiele; jednak w nielicznych tylko pracach znajdziemy opis modelowania środowiska językowego. Bada się grupy społeczne, prowadzi się błyskotliwe dyskusje na temat ich uporządkowania formalnego, natomiast implikacje i skutki językowych aspektów procesu komunikacji, w jakim te grupy uczestniczą, wydają się niegodne uwagi socjologa. Absolwenci socjologii potrafią prowadzić badania ankietowe, zestawiać kwestionariusze, robić wywiady; w toku studiów jednak nie przeszli - przynajmniej w Anglii - żadnego systematycznego przeszkolenia w zakresie wyodrębnionym przez Della Hymesa jako etnografia mówienia, choć uznaje się, intuicyjnie i niekonsekwentnie, istnienie różnic we wzorach i następstwach zdarzeń mówienia w różnych subkulturach" (Bernstein, 1980, s. 85; Sawisz, 1989; i inni).

Cytowany autor jest przekonany, że podczas formowania samego aktu mowy u dzieci i młodzieży otaczająca struktura staje się psychologiczną rzeczywistością rozwijającego się dziecka. Ten ogólny wzorzec mowy jednostki tworzy krytyczne zestawy wyborów oraz preferencji dla pewnych alternatyw. Utrwalając się w trakcie procesów socjalizacyjno-wychowawczych; zestawy te zaczynają określać intelektualną, społeczną oraz uczuciową orientację jednostki. Podobną sytuację stwarzają liczne elementy kultury masowej przejawiające się w różnych formach wśród dorosłych członków społeczeństwa.

W ujęciu bardziej sformalizowanym jest to uczenie się pewnych przypisanych jednostce zachowań wskutek uczestnictwa w społecznym procesie przekazu informacji, zwanym często także procesem komunikacji. Rola społeczna w tym ujęciu jest po prostu konstelacją wyuczonych znaczeń. Jeżeli wychowankowie/odbiorcy mają dostęp do różnych systemów mowy, to znaczy jeśli w procesie socjalizacyjnym uczą się oni różnych ról odpowiadających ich statusowi w danej strukturze społecznej, to z reguły przyswajają sobie zupełnie odmienne wzorce mentalno-kulturowe, w tym także różne sposoby zachowań, określonych jako procedury społeczne oraz intelektualne, nawet wówczas, gdy ich możliwości intelektualne są identyczne (Bernstein, 1980, s. 95).

Następnie Bernstein wprowadza - co jest szczególnie charakterystyczne dla jego teorii - dwa podstawowe pojęcia kodu:

- kod rozbudowany (elaborated code),

- kod ograniczony (restricted code).

Kod to oczywiście system umownych znaków, sygnałów, haseł używanych do przekazywania określonych wiadomości przez nadawcę kierowanych do odbiorcy (Kopaliński, 1971, s. 38). 
Na płaszczyźnie językowej określa je prawdopodobieństwo odgadnięcia, jakie elementy składniowe wykorzysta wychowawca, tzn. nadawca (socjotechnik), osoba mówiąca bądź pisząca dany komunikacyjny przekaz w organizacji samego znaczenia (określonych symboli) w obrębie reprezentatywnej próbki mowy czy tekstu. Osobnik stosujący typ kodu rozbudowanego uwzględnia stosunkowo obszerny zakres alternatyw, stąd też możliwość odgadnięcia, jakie elementy wybierze on do organizacji znaczenia, podlega znacznej redukcji. Na przykład ojciec opowiada dziecku nową bajkę, przerywając w trakcie opowieść i zadając pytanie: „Jak myślisz, co się później stało?”. Tworzy się wówczas warunki - jak twierdzi Bernstein - wypowiadania i wyrażania kreatywnych pomysłów i opinii na podstawie uprzednich doświadczeń wychowanka. W tej sytuacji trudno wychowawcy przewidzieć, jaki będzie dalszy ciąg opowieści relacjonowanej przez dziecko. W specyfice języka angielskiego dominuje strona bierna (passive voice). Zostało powiedziane, byłoby zrobione itp. Np. absolwent szkoły elitarnej w Eton, pytając o możliwość zapalenia papierosa w towarzystwie, w którym przebywa, z pewnością użyje formuły: Would you mind if I had a smoke?! Używając kodu bardziej ograniczonego, zapytamy raczej: Can I please have a smoke?

Inna sytuacja występuje natomiast w przypadku stosowania typowego kodu ograniczonego. Użytkownik tego kodu wybiera najczęściej jedną spośród niewielu alternatyw, wobec czego wzrasta prawdopodobieństwo odgadnięcia, które elementy zostaną zastosowane w strukturze relacji, czy też opowiadania w ramach jednostkowej wypowiedzi. Oto matka, opowiadając dziecku bajkę znaną dobrze im obojgu (wielokrotnie uprzednio czytaną i opowiadaną), np. o wilku i Czerwonym Kapturku, i relacjonując moment wejścia Czerwonego Kapturka do sypialni babci, stosuje rytualną pauzę, stawiając następnie pytanie: „Jak myślisz, i co się dalej stało?”. Przywołamy w tym miejscu samego Bernsteina: jeśli matka pragnie przekazać swe jednostkowe doświadczenie, musi to uczynić inaczej niż za pomocą słów. Jedyną możliwością staje się w tej sytuacji zmiana sygnałów przekazywanych kanałami pozawerbalnymi: zmiana intonacji głosu, rytmu mowy, wymowa twarzy, gesty lub nawet zmiana naprężenia mięśni, jeśli np. trzyma dziecko na rękach. Kod określa kanały, jakimi można udostępniać nowe informacje (czyli uczyć). Interpersonalny aspekt kontaktu matki i dziecka - kontaktu, którego podstawą są ich jednostkowe intencje, może się realizować tylko w sferze środków pozawerbalnych. Do nich przynależy mimika twarzy, gesty, zmarszczenie brwi itp., towarzyszące nakazującemu hasłu głoszonemu wielokrotnie przez przewodniczącego Samoobrony: Balcerowicz musi odejść, 
czy obecnie rytualnej udzielanej odpowiedzi na wszelkie pytania wiążące się z pojawiającymi się niedomaganiami dnia wczorajszego bądź dzisiejszego skwitowanymi frazesem: wina Tuska. Jeśli wybór sekwencji jest z góry przesądzony, to udostępnienie nowej informacji wymaga wykorzystania kanałów pozawerbalnych; kanały te staną się wtedy przedmiotem szczególnej aktywności percepcyjnej. Kod określa więc formę relacji społecznej przez to, że ogranicza możliwość werbalnego sygnalizowania różnic indywidualnych. Podstawą wzajemnych relacji rozmówców stają się ich pozycje społeczne lub osiągnięty status. Różne społeczeństwa różnie ów kod ograniczony wykorzystują, niejednakowe są też warunki jego występowania.

Inny przykład może stanowić sytuacja przedstawienia przez gospodarza spotkania towarzyskiego dwóch obcych sobie osób, spotykających się po raz pierwszy na przyjęciu. Akt prezentacji pociągnie za sobą prawdopodobnie stosowanie najpierw kodów ograniczonych - zwrotów grzecznościowych czy rytualnych zachowań. W dalszej części rozmowy, pod warunkiem dużej wrażliwości rozmówców na wszelkie sprawy pozawerbalne, istnieje możliwość przejścia na kod rozbudowany, między nimi po to, by stworzyć obojgu satysfakcję wypływającą często z osobistego przekonania o dotychczasowym pomyślnym rozwoju własnej osobowości, bądź też z chęci przekazania partnerowi rozmowy pewnych indywidualnych i osobistych doświadczeń.

Bernstein twierdzi stanowczo, iż na płaszczyźnie psychologicznej omawiane kody wyróżnia to, że pierwszy (kod rozbudowany) pobudza rozwój jednostki, a drugi (kod ograniczony) hamuje tendencję do werbalnie eksplikacyjnego formułowania osobistych intencji wychowanków (odbiorców komunikatu). Każdy typ kodu wytwarza własne matryce zachowań, a zachowania te kształtują odmienne systemy samosterowania, a więc różne formy orientacji. Same kody, stanowiące określoną formę relacji społecznych, wpływają - pośrednio i bezpośrednio - na nasze efekty wychowawcze i kształceniowe. Autor uzasadnia to niezłomnym przekonaniem, że składnik językowy, czyli czynnik werbalny, określa te przekazy, a ich znaczenie przenoszą same słowa mowy ludzkiej; ich dobór, układ wzajemny, kombinacja bądź też organizacja. Składnik parajęzykowy, ów pozawerbalny, dotyczy natomiast znaczeń przenoszonych przez ekspresyjne komponenty słów (rytm, akcent, ton itp.), albo też przez same gesty, konfigurację fizyczną, czy po prostu określoną mimikę twarzy. Taki właśnie zakres wiadomości wskazuje Bernstein rodzicom i nauczycielom jako konieczny i niezbędny program działania wymagający jednak wcześniejszego zrozumienia, a zatem przyswojenia wielu zjawisk i faktów z zakresu ogólnej wiedzy pedagogicznej (Bernstein, 1980, ss. 95-97; 
Radziewicz-Winnicki, 1993, ss. 17-20). Z tej perspektywy (zarówno socjologii fenomenologicznej, jak i etnometodologii akty komunikacji - szczególnie językowej - stanowią podstawowe mechanizmy przyzwalające osobnikowi/ jednostce pokonać ograniczenia indywidualizmu i podporządkować je wartościom, normom, wzorom życia społecznego.

Orientacja dziecka na stosowanie kodu rozbudowanego bądź też kodu ograniczonego w trakcie licznych wypowiedzi słownych może być faktem zupełnie niezależnym od samej jego psychiki i zdolności wrodzonych. Od czysto psychologicznych właściwości osobowości wychowanka zależy jedynie poziom operowania samym kodem, natomiast o typie stosowania kodu czy tzw. jego jakości decyduje niemal wyłącznie środowisko wychowawcze. Zdaniem Bernsteina, względnie opóźniony rozwój dzieci niższych warstw społecznych można i trzeba wyrównać świadomym i racjonalnym działaniem intencjonalnym nauczycieli w szkole zgodnie z pomyślnym prowadzeniem tej szczególnej misji (Por. Lewowicki, 2007a, 2007b; Śliwerski, 2015; Szempruch, 2010, 2013; Gajdzica, 2013).

Dobrze byłoby zatem, reasumując obecnie dotychczasowe uogólnienia, podać istotne właściwości poszczególnych kodów, w chwili stosowania metod określonego typu wpływu polityczno-socjotechnicznego, w następstwie pojawiającym się przekazie medialnym.

Kod ograniczony charakteryzuje się krótkimi, przeważnie niedokończonymi zdaniami o prostej, ubogiej konstrukcji. Zdania są niezawiłe, bardzo często powtarzają się użyte spójniki. Utrudnionym zadaniem staje się wówczas dla dziecka budowanie złożonych ciągów logicznych, przekazujących związki emocjonalne oraz logiczne relacje pomiędzy zjawiskami. Ujawnia się brak logiki i powiązań między realiami a sądami wartościującymi i otaczającą je rzeczywistością.

Sztywne i szczególnie ograniczone użycie przedmiotów i przysłówków związane jest $\mathrm{z}$ tendencją do prostego i wybiórczego określenia otaczającej rzeczywistości, bez podawania dodatkowych - zbędnych w ocenie mówiącego - informacji. Często stosowane są zaimki osobowe. Częste - wręcz nagminne - staje się także wydawanie w prostych zdaniach w trybie rozkazującym określonych poleceń, mających spowodować u partnera rozmowy określone zachowania, traktowane przy tym jako ostateczny argument nie tyle rozmowy, co komunikatu (np. Pójdź tam, ale szybko! Dlaczego? Bo ja tak chcę! i to już! Musisz tak zrobić, no wiesz! Ty wiesz you know), wręcz polecenia pojawiającego się bardzo często w tego typu przekazie (Bernstein, 1980, ss. 95-96, 113-114). 
Nie wchodząc w szczegóły specyfiki języka angielskiego, które stanowią podstawę analiz, można powiedzieć, iż stosowanie kodu ograniczonego jest zarazem - w każdym języku - stosowaniem pewnych znaczeń ukrytych. Wypowiedzi charakteryzują się bardzo niskim stopniem ogólności. Symbole czy stereotypy (lokalne, regionalne bądź narodowe) zastępują określenia zależności logicznych. Akcentowana jest także wspólnota (solidarność), a w zasadzie cały obszar kultury grupowej osób posługujących się zbliżonym bądź identycznym typem mowy (Rogalska-Marasińska, 2017).

Trzeba też uświadomić Czytelnikowi, przed przejściem do kolejnej części artykułu, że potrzeba zmiany w naszym państwie uświadamiała się w naszym kraju w wolnym trybie, ale za to konsekwentnie. Występowały także podobne postulaty w innych państwach określanych jako socjalistyczne czy demokracji ludowej (tzw. demoludy) już w końcu lat 70. ubiegłego wieku. Dotyczyły mniej lub bardziej śmiałych modyfikacyjno propozycji samych członków partii rządzącej, jak i partii stowarzyszonych (ZSL, SD), a przede wszystkim milionowych rzesz osób bezpartyjnych i Kościoła. Trudno nawet było oczekiwać, by dopominają się o własną tożsamość zbiorowości, o większą swobodę polityczną we wprowadzanie elementów gospodarki rynkowej wyznawców idei zawartych w teorii konwergencji, czy rychłą egzystencję w strukturze socjalistycznej wolnych związków zawodowych, były w tej fazie próby przedkładania przeszłościowej własnej wizji naszej części Europy szczegółowo zainteresowane naszymi przyszłymi międzynarodowymi sojuszami. Przewidywano, że Polska wraz z „Solidarnością” pozostanie w bloku radzieckim, tyle że gospodarka będzie bardziej liberalna, a struktury polityczno-społeczne nawiązywać będą do modelu pohelsińskiego (Mikułowski-Pomorski, 1995, ss. 10-13). Dopiero później następuje rewizja pierwotnej percepcji funkcjonowania struktur Europy i żywotność tematyki międzynarodowej przy naszym współudziale, i narastającym o dziwo zróżnicowaniem światopoglądowym, w tej bardzo wyróżniającej się narracji prowadzonej przez członków i sympatyków późniejszego PiS.

\section{Przykłady słowotwórczej (zakodowanej) narracji wywierania wpływu}

Przede wszystkim dominuje obecnie od pięciu lat w krajowych mediach publicznych (o czym pisał już wcześniej Bernstein) w obrębie kodu ograniczonego przeważająca liczba przysłówków. Także w relacjach/przemówieniach działaczy partyjnych i rządowych. Często występują stereotypy emocjonalnie 
zabarwione, a także wieloletnio i kilkupokoleniowo przekazywane w danej kulturze, które mają świadczyć o rzekomych wiarygodnych i w pełni obiektywnych przekonaniach większości ${ }^{5}$. Idzie nadawcom komunikatów i stosowanym przez nich słowotwórstwie wypowiedzi o wykorzystanie jego wpływu na kształtowanie się określonych postaw, uwzględniających w miarę trwałą tendencję do pozytywnego, bądź to negatywnego na dany kod reagowania wartościującej przez odbiorcę. W zdecydowanej ich większości kody nie dopełniają się w sposób logiczny i spójny w nadawanym przekazie informacyjnym. Sprzyja niewątpliwie takim zasobom i możliwościom wywieranie skutecznego wpływu m.in. z uwagi na podobieństwo poglądów (na politykę, sport, gospodarkę itp.) zarówno nadawców, jak i odbiorców, bądź to wywoływanie tzw. reguły niedostępności. Jak prezentuje ją Dariusz Doliński - na podstawie przyjętej psychologicznej teorii reaktancji (theory of psychological reastance) - która głosi, że jeżeli jakiś przedmiot/dobro lub też przywilej, dostępny i dozwolony do tej pory, zostanie odebrany lub też ograniczony zostaje dostęp do niego, albo jeżeli chociażby pojawia się zaledwie groźba ich odebrania (np. program 500 plus w przypadku wygrania wyborów przez dzisiejszą opozycję), to zyskują one na swojej niezbywalnej wartości, determinując przy tym pewne środowiska wyborców i masowo opiniotwórcze grupy (Doliński, 2005, ss. 382-383), ku aktywnej wrogości i konfrontacji, wykluczającej jakiekolwiek współdziałanie.

W środowiskach robotniczych przeważa z zasady - zdaniem Bernsteina kształcenie i wychowanie tradycyjne i nieuświadomione, nastawione na przyjęcie w przyszłości przez wychowanków określonej pozycji społecznej; wybór oczekiwanego przez rodziców zawodu, preferowanie wartości będących egzemplifikacją aktualnie reprezentowanej subkultury lokalnego środowiska wychowawczego (najczęściej rodzinnego).

W klasie średniej dominuje natomiast tzw. otwarty typ wychowawczy w zakresie przygotowania dziecka do pełnienia w przyszłości bliżej jeszcze niesprecyzowanej roli społecznej. Zdecydują o tym doświadczenia życiowe jednostki, zindywidualizowane cechy psychiczne itp. Zadaniem szkoły i wychowawców staje się zatem kształtowanie mowy i intelektu dziecka, nastawione na używanie kodów wyłącznie rozbudowanych (otwartych) ${ }^{6}$ we

5 O być może nieświadomej, ale pełnej indokrynacji kulturowej w Polsce, na przykładzie stosunku publicznej większości do oceny romantyzmu polskiego, bardziej szczegółowe analizy można odnaleźć w innym opracowaniu (Radziewicz-Winnicki i Wilk, 2019).

6 Podobnie sugerują polscy autorzy: „[...] Wydaje się czasem, iż intencją autora 
wszystkich relacjach między nadawcą a odbiorcą. Traktuję sygnalizowaną powyżej misję nauczycielską jako naczelne zadanie w zbiorowym przeciwstawianiu się światłej, publicznej i niepublicznej, kreacji przeciwko agitującej symbolice kodów ograniczonych występujących nagminnie w telewizji publicznej czy to innych przemówieniach, np. w trakcie organizowanych przez wiele już lat miesięcznic smoleńskich, czy też innych formach przekazu i ich socjotechniczną naturą konsekwentnie podejmowaną w politycznej intencji nadawcy, a przy tym w oczekiwaniu, że odbiorca emitowanego przekazu uzna dany komunikat za prawdziwy i przekonujący, wywołujący określone rezultaty wyborcze. Oto niektóre dobrane hasła, interpretacje, wypowiedzi, wartości, normy i wzory postępowania przybierające zdecydowanie socjotechniczne oblicze ${ }^{7}$, a które wszystkie mieszczą się w pojemnym zbiorze kodów ograniczonych Basila Bernsteina (Karabel i Halsey, 1997, ss. 68-71). Oto one, a w zasadzie niektóre $\mathrm{z}$ wielu, m.in. wymienione przez autorów znakomitego opracowania edytowanego w roku ubiegłym, na które się często powołuję w tym opracowaniu: podwójne standardy brukselskich elit czy czerwony sen brukselskich elit; komu opłaca się Unia Europejska?; damy radę; Polska mocy kontra Polska niemocy; dobra zmiana; dojna zmiana; dobry czas dla Polski; Polska nie godzi się na dyktat Brukseli; wymiana elit; przebudowa elit; genderowa tęczowa zaraza, genderowy'; haniebny, hańba, imposybilizm, kasta,

jest wykazanie, że to właśnie szkoła reprezentuje taki negatywny punkt widzenia na kod ograniczony, głównie zresztą z powodu jego mniejszej przydatności w procesie nauczania. Zależy to od klasowej przynależności większości nauczycieli, ale wynika przede wszystkim z samego charakteru systemu szkolnego, sposobu określenia zadań i celów szkolnictwa oraz ustalenia kryteriów osiągnięć w nauce. Ostatecznie można by powiedzieć, że niepowodzenia szkolne nie są spowodowane tylko faktem, że dziecko zna jedynie kod ograniczony czy też w określony sposób dokonuje obserwacji świata, ale wynikają także z jego nieprzystosowania do systemu szkolnego, a z drugiej strony z zasadniczej niezależności przez nauczycieli potrzeb, celów i możliwości dzieci z klasy robotniczej" (Bokszański, Piotrowski i Ziółkowski, 1977, s. 120; Szempruch, 2018, 2020).

7 Socjotechnika, czyli inżynieria społeczna, to nauka, dziedzina teoretyczna zajmująca się m.in. badaniem i analizowaniem racjonalnych i z wysokim prawdopodobieństwem sprawczych intencjonalnie zorientowanych oddziaływań, skupiających się głównie na ich skuteczności. Mają on na celu przy pomocy psychologiczno-socjologicznej orientacji uzyskać zamierzony efekt modyfikacji rzeczywistości społecznej, wpłynąć na oczekiwane pożądane z punktu widzenia sprawcy zachowania jednostki/ grupy.

8 Warto poszerzyć interpretacje, szczególnie waloryzowanego przez PiS terminu. 
nadzwyczajna sędziowska kasta, kolesie, komuniści i złodzieje, resortowe dzieci; kanalie, mordy zdradzieckie; multi-kulti, niezłomni, nieugięci, żołnierze wyklęci; ojkofobia (domowstręt, niechęć do własnej ojczyzny, nienawiść do własnego narodu); państwo teoretyczne; patriotyzm, marsz patriotów (czysta krew, Polska bastionem Europy, Biała Europa bohaterskich narodów - hasła marszów niepodległości 2015 i 2016 odbytych w Warszawie, o zabarwieniu nacjonalistyczno-rasistowskim); między pedagogika wstydu a pedagogika dumy; postkomunizm; my stoimy tu, oni tam gdzie ZOMO; prawda, dochodzimy do prawdy; przemyst pogardy; rodzina, wara od naszych dzieci, seksualizacja dzieci; Smoleńsk, krew na rękach, zamach smoleński, apel smoleński, apel pamięci, miesięcznica smoleńska; rodziny smoleńskie; sort, najgorszy sort Polaków; spisek w Magdalence; sukces; targowica, plucie na Polskę, zdrada, zdrajcy, targowiczanie; taśmy, taśmy prawdy, układ gdański, układ samorzadowy, wina Tuska, wilcze zęby Tuska, wilcze oczy Tuska; wstawanie z kolan, kradzież, wystarczy nie kraść, uczciwa praca, te pieniadze się im po prostu należały i wiele, wiele innych (Kłosińska i Rusinek, 2019). Wszystkie one mają wywołać uczucie integracji międzygrupowej wśród rzeczników sygnalizowanych powyżej kodów/idei, przywołać oczekiwane przez nadawcę uczucie/ odruch wzburzenia, piętna w stosunku do nich tych Obcych, którzy przez dwie poprzednie kadencje stanowili wiodącą siłę w państwie. Wszystkie kody prezentowane są w dychotomicznym i perswazyjnym podziale: swój (nasz, własny) versus obcy (wrogi) nie swojski; dobry a zły; skuteczny a nieskuteczny; wtaściwy i niewtaściwy. Odbieram je osobiście jako praktykę (skuteczną) na prowokacyjne uwrażliwienie odbiorcy. Podawane są z reguły jako komunikaty jednostronne, o tyle skuteczne, że odbiorca o niezbyt wysublimowanym intelektualnie charakterze, nie uświadamia sobie istniejącej jakiejkolwiek innej alternatywy która musiałaby zaistnieć w przypadku przekazania argu-

Od pojęcia gender tworzy się przymiotnik genderowy, który w trakcie wypowiadanych treści wykazuje bardzo nieprecyzyjny, a często wadliwy wręcz charakter przeciwstawiający „wartości katolickie, w tym polskie, kontra genderowe”. Ta ekspresja - jak piszą Kłosińska i Rusinek - dotyczy m.in. wyimaginowanych problemów migracji zawartych w tweecie posłanki i orędowniczki PiS-u Krystyny Pawłowicz: „»Goście « podpalają Szwedom lasy, samochody, tłuką policjantów, kradną, biją, gwałcą i mordują... Szwedzi nie pozwalają o tym nawet mówić ani oskarżać. Szwecja, najbardziej genderowe, zabijające naturę ludzką państwo, już nie reaguje". Lub też inny ciąg skojarzeń o obliczu wpływu społecznego: „Adamowicz traktuje Gdańsk jako swój lewacko-niemiecko-genderowy folwark. $Z$ tego powodu jest pieszczochem Berlina, a nasza dyplomacja nie śmie nawet szepnąć słowa o interesach Polaków, »reparacje, jugendamty i status mniejszości « to pan prezydent robi, co tylko chce" (Kłosińska i Rusinek, 2019, ss. 76-77). 
mentacji dwustronnej, tj. zgodnie ze stanowiskiem własnym oraz odrębnym wyrażanym przeciwko niemu (Doliński, 2005, s. 384; Kowalski, 1990). Oczywiście kategorie Swój i Obcy należą przecież od lat do najbardziej powszechnych pojęć używanych do opisu relacji strukturalnych pomiędzy jednostkami i grupami społecznymi ${ }^{9}$. Pojmowanie zachowań w tych kategoriach pozwala nam zrozumieć rdzeń nienawiści, antagonizmów, sprzeczności, jak również fascynacji, aprobaty czy aspiracji towarzyszących ewentualnie nam w poznawaniu i doznaniu wszelkiej inności. Nadzwyczaj ważna jest obcość stymulowana przez kreatora i dystans społeczny w sferze, który towarzyszy emocji jako miara dezaprobaty (dystansu społecznego), dobrze znana współczesnej socjologii i antropologii kulturowej (Nowicka, 2005, ss. 166-157; Park, 1924; Bogardus, 1925; Work i Gallier, 2007).

Sport w służbie polityki występuje w tych przekazach nad wyraz często z intencją mobilizowania i integrowania opinii publicznej szczególnie często nawiązuje do wydarzeń, a zwłaszcza rozgrywek (meczów) międzypaństwowych. W takich chwilach, kiedy zwycięstwo białoczerwonej drużyny jest oczekiwanym jej sukcesem, to z racji odniesionego zwycięstwa rząd się z nim w pełni utożsamia. Wygrana staje się sprawą czci i honoru całego narodu powstajacego $z$ kolan i niezwykle mocno wydaje się wzmacniać w tym pań-

9 Przed oczami przywoływany zostaje w mojej banalnej retrospekcji udział (dwukrotny czy też trzykrotny) w Ambasadzie Chińskiej Republiki Ludowej na organizowanych czwartkowych spotkaniach ze studentami polskimi, dyplomatycznych władz tej Ambasady w okresie tzw. Rewolucji Kulturalnej, chyba w 1966 lub 1967 roku. Po oficjalnym zakazywaniu przez J.M. Rektora i Senat Uniwersytetu Warszawskiego uczestnictwa w takich spotkaniach pod groźbą bliżej niesprecyzowanych restrykcji my, studenci Wydziału Filozoficznego (socjolodzy i filozofowie), gremialnie braliśmy w nich udział, pociesznie i komediowo traktując wypowiedzi chińskich gospodarzy wygłaszanych w naszym rodzimym języku trudnym - nie wspominając już o akcencie towarzyszącym wymowie - we właściwej percepcji ich zrozumienia. W pamięci pozostał mi wyłącznie obraz jego schematu, identyczny niezależnie od rodzaju stwarzanych licznie pytań przez młodych humanistów (np. Stosunek Chin Ludowych do abstrakcyjnego malarstwa Pablo Piccasso?, Zagospodarowanie terenów wiejskich?, dbałość o dobrostan zdrowotny młodego pokolenia Chińczyków? Import setek tysięcy wróbli z terenów miejskich z Francji do Pekinu?, i wiele innych); że formuła odpowiedzi zawsze i niezmiennie pozostawała identyczna. Brzmiała ona bardzo schematycznie, wręcz sztampowo: „...za czasów bandyty, kontrrewolucjonisty i zdrajcy Chan Kai-szeka... - tu padały niecenzuralne słowa, których nie wymienię... - Zastano określoną sytuację..., a pod wodzą przywódcy Towarzysza Mao Tse-tunga nastały wreszcie oczekiwane czasy wszechobecnego komunizmu, który przejawia się..." itd. 
stwowym przekazie jakże często nacjonalistyczne i ksenofobiczne postawy. Sukcesy sportowe stanowią pierwszoplanowe informacje w programach telewizyjnych i radiowych; porażki, zwłaszcza te nieprzewidywalne, wywołują duże zaskoczenie wielomilionowej widowni i stanowią już tylko ogony serwisów informacyjnych ${ }^{10}$, a zdarza się, że w ogóle zostają zmarginalizowane czy wręcz pomijane (Rudzki, 1962, ss. 200-201). „Białe róże” przynoszone przez uczestników konkurencyjnych, trwających równolegle $\mathrm{z}$ „miesięcznicami smoleńskimi” manifestacji pojawiających się z nastaniem 2016 roku stanowić zaczęły symbol agresji i niezgody. „Dziś mamy (...) nowy wielki akt nienawiści, bo te białe róże, które tam widać, to właśnie symbol nienawiści i głupoty, skrajnej głupoty i skrajnej nienawiści”. Nastąpiło tu - zdaniem krytyków - zawłaszczenie symbolu oporu przeciwko nazizmowi w Niemczech, który symbolizują białe róże, jak i odebranie znaczenia innego niż utrwalone w kulturze, uzurpujące sobie (w osobie lidera partii) władzę symboliczną nad językową (Kaczyński, 2017).

Biel, zawsze kojarzona z dobrem, stała się w cytowanym przekazie symbolem zła, które wyznaczone zostało z emocjonalnie płonącej nienawiści. Mamy więc - jak piszą wielokrotnie przeze mnie przywołani krytycy słownictwa partii "dobrej zmiany” - do czynienia z orwellowskim literackim zabiegiem odwracania znaczeń (jeśli pamiętamy, widniały trzy hasła na ścianie budynku Ministerstwa Prawdy Oceanii: „Wojna to pokój”, „Wolność to niewola”, „Ignorancja to siła” (Orwell, 1989, s. 7; Kłosowska i Rusinek 2019, ss. 34-35). Towarzyszą podjętym przekazom zasady marketingu reklamowego. Reklama nie przemawia z reguły za pomocą perswazji, ale stanowi ona jej jądro - slogan łatwy, poczytny i prosty do zapamiętania, a zarazem szybko utrwalający się w świadomości. Bywa on często natrętny. Formowanie stereotypów odbija się i kopiuje w ten sam sposób w różnych postaciach i możliwych tylko wersjach. Sugestywnie sformułowane i powielane hasło o zabarwieniu politycznym, niejednokrotnie pojawiające się żądanie, obligujące wezwanie, a zwłaszcza karykaturalny wizerunek danej postaci, wywiera wpływ na wyborców, tych o uproszczonej wrażliwości emocjonalnej. Rozrachunek z przeszłością - nagminnie prowadzony - także sformułowany jest w kategoriach nacjonalistycznego zabarwienia. Trudno powiedzieć, jak przedstawia się ilościowy podział wśród przywołanej i sygnalizowanej tema-

10 Biato-czerwona drużyna to kod o jednoznacznym znaczeniu, pozytywnie kojarzy się z Polską i ze sportem. Rząd stanowi taki właśnie biało-czerwony team (w wyrażeniach premierów: Szydło i Morawieckiego). Porażki są wliczane do innego kodu sportowo-ulicznego: Polacy, nic się nie stało! 
tyki, bowiem nie znam w kraju do tej pory jakichkolwiek badań z tego okresu przygotowanych za pomocą tradycyjnej metody analizy treści (por. Rudzki, 1962, ss. 188-189). Jednak już sam przegląd wymienionych haseł (kodów) wyznacza przyjęty przez PiS profil wygłoszonych - uznanych przez siebie jako najważniejsze i szczególnie skuteczne w recepcji zbiorowości preferencje tematyczne. Są to kody językowe zawierające w zdecydowanie przeważającej części uaktywnioną intencjonalnie prowokacyjną przesadę.

Kończąc kolejną część artykułu, pragnę zapewnić Czytelników, a przede wszystkim nauczycieli, iż następne propozycje Basila Bernsteina - których już nie przytaczam z uwagi na jego objętość - m.in. dotyczące reguł stosowania tzw. widocznej i niewidocznej pedagogiki/pedagogii (visible/invisible pedagogy) zawierają treści dyrektywne stanowiące podstawę procesu pedagogicznego i przyjętą jako kanon działania wszystkich społeczności prawie całego świata. Są to założenia i reguły prakseologiczne. Bernstein jest głęboko przekonany, że działania nauczyciela, zarówno ukryte, jak i jawne, powinny być realizowane w taki sposób, aby wszystkie elementy procesu pedagogicznego i wszystkie czynności nauczyciela-wychowawcy przyczyniały się do osiągnięcia celów oczekiwanych przez nadawcę, tj. osobę stymulującą dane działania, przy równoczesnym zachowaniu indywidualizmu w przyjętej ideologii kształcenia. Samego Bernsteina, podobnie jak i wielu innych badaczy zasad ogólnych sprawnego działania, absorbuje problem kompletowania i porządkowania ogółu wskazań racjonalnego działania. W zamierzeniu autora owo kompletowanie i porządkowanie reguł powinno przyczynić się do jeszcze bardziej efektywnych i racjonalnych przedsięwzięć wychowawczych. Działania ukryte i jawne stosowane przez wychowawcę wobec wychowanka mają pewien społeczny kontekst zachowań, w których trzeba koniecznie wyróżnić trzy cechy warunkujące analizowany kontakt. Są nimi: zasady społecznej hierarchii działania, reguły kolejnościowe określone jako tzw. priorytety działania oraz kryteria decydujące o percepcji przekazywanych treści (Bernstein, 1975, ss. 49-69; Bokszański i Piotrowski, 1990, ss. 33-71). Omawia on również ich wagę i znaczenie w rozwoju poszczególnych społeczności lokalnych i klas społecznych. Porusza pewne aspekty kontroli społecznej i zaangażowania środowiska lokalnego w ogólne problemy edukacji. Przedstawia więc liczne kwestie współudziału społeczności lokalnej czy regionalnej w tworzeniu programu nauczania, a także w samej formie przekazu dydaktycznego. W dalszej części rozważań wyróżnia wskaźniki intensywności działań dydaktycznych nauczycieli oraz kontrolę rezultatów poszczególnych dokonań, przeprowadzoną wyłącznie metodą analiz pewnych czynników (faktorów) 
występujących w środowisku życia, tj. zamieszkania, wychowania, czy też egzystencji odbiorcy, we własnym środowisku lokalnym (por. Radziewicz-Winnicki, 1993, ss. 22-24).

Niezależnie od ich teoretycznej i praktycznej indywidualizacji i specyfiki języka angielskiego ${ }^{11}$ taka oryginalna forma spojrzenia na współczesną pedagogikę koniecznie winna skupić uwagę licznych przedstawicieli naszego zbiorowego obszaru rodzimej edukacji. Bardziej zainteresowanym Czytelnikom można polecić literaturę przedmiotu szerszą niż ta cytowana przeze mnie.

\section{Resentyment w dobie transformacji postmonocentrycznej}

Sygnalizowane uprzednio populistyczne idee stanowiące kody zamknięte wchłaniane są (przyswajane) przez dużą część społeczeństwa polskiego. Dzieje się to przy bieżącym nieustającym ich wspomaganiu (wsparciu) globalizującej się nieustannie i niebezpiecznej współczesności towarzyszącej intensywnie przebiegającej transformacji kulturowo-społecznej i gospodarczej. Dylematy bytowe i egzystencjalne powstają nagminnie od trzech dekad, towarzysząc przebiegającej wokół transformacji. Uzewnętrzniają się rozliczne dylematy moralne zarówno wśród młodzieży, jak i osób dorosłych, pojawiające się wśród rozchwianych systemów wartości i norm etycznych, uwarunkowane również doświadczeniami zakorzenionymi od czasu tzw. realnego socjalizmu. Całokształt przemian jawi się nam na czasowo nieograniczonej osi: tradycja, modernizacja a ponowoczesność. Ścierają się ponadto z wymienionymi elementami różne orientacje na wzory zachodniej cywilizacji i kultury (Mariański, 1995, s. 9). Zatem sytuacja współczesna staje się pilnym do rozstrzygnięcia kryzysem intelektualnym tak dla teoretyków, jak i praktyków. Może on być różnie oceniany zarówno przez zwolenników liberalnej demokracji, jak i komunitaryzmu w dwojaki sposób. Pierwszy zakłada, że zjawiska

11 Można również postawić autorowi tego artykułu pytanie: Czy uzasadniona jest jego rekomendacja w sprawie poglądów, opinii, koncepcji brytyjskiego uczonego polskiemu czytelnikowi? Odpowiedź nasuwa się - w moim przekonaniu - wyłącznie jednoznaczna. Jego trzytomowe dzieło (Bernstein, 1971, 1974, 1975) zostało przetłumaczone na kilka języków w świecie. Ponadto dominująca część światowej naukowej literatury ukazała się przecież drukiem w języku angielskim. Angielskie teorie i doktryny naukowe znajdują licznych zwolenników i naśladowców w wielu - ponad 50 - krajach Commonwelthu. Chociażby tylko z przytoczonych powyżej powodów podjęte rozważania zasługują - o ile nie są w pełni zasadne - na pilną uwagę polskiego Czytelnika. 
towarzyszące zmianie społecznej są nieuniknionym następstwem degradacji naszej cywilizacji, którą wywołały niekontrolowane procesy rozwoju demograficznego, urbanizacji, industrializacji i skażenia przyrody - środowiska naturalnego człowieka. Drugi z kolei ocenia fakt ów zgoła odmiennie. Zgodnie z tym stanowiskiem liczne społeczności mają do czynienia z dramatycznymi trudnościami okresu przejściowego, czasów przemian, podczas których cywilizacja na wszystkich kontynentach zmienia swe formy i treści. Przyjęcie pierwszego poglądu pociąga za sobą przekonanie, że z faktem tej degradacji związany jest zanik wielu systemów wartości i tradycyjnie wykształtowanych w przeszłości struktur społecznych.

Z drugim stanowiskiem wiąże się inny pogląd. Stwierdza on, że utrata i zanik określonych wartości, struktur itp. wynika ze zwykłej organizacji struktur społecznych, bądź też zaczniemy snuć rozważania, jakimi drogami w krótkim czasie przebudować strukturę tych społeczności, w sposób całkowity i zdecydowanie radykalny (por. Wallis, 1984, s. 3). Na tak postawione pytania każdy odpowiedzialny kreator życia publicznego musi sobie udzielić właściwej odpowiedzi w trybie indywidualnym, w oparciu o dowody naukowe i rzetelną wiedzę, minimalizując rolę tradycji. Jako pewnik/nakaz i tautologiczną maksymę przyjąć musimy regułę, iż jednostką, społeczeństwem i przestrzennymi warunkami egzystencji człowieka nie można dowolnie manipulować, bez narażania go (głównie z powodu być może luk we własnym wykształceniu, niewiedzy i braku kompetencji) na jakiekolwiek deformacje, perturbacje i mogące nastąpić po sprawczym nieuzasadnionym działaniu patologie (zob. Wallis, 1984, ss. 3-4; Radziewicz-Winnicki, 1984, ss. 9-10). Zapobiec im może tylko rzetelne oraz wiarygodne compendium różnych typów wiedzy (interdyscyplinarnej), uwzględniającej konieczność stosowania historycznej i porównawczej perspektywy przeprowadzonej na podstawie wymiernych parametrów naukowych.

Wśród reprezentantów nauk społecznych tego typu problematyka nie cieszy się dużą popularnością, zwłaszcza w pedagogice i socjologii. Istnieje jakieś (?) przekonanie, iż można ją przedstawić za pomocą innych pojęć psychologicznych, takich jak relatywna deprywacja czy pojęcie: traumy, politraumy, bądź to frustracji. Te pojęcia pomijam w dalszym toku analiz $\mathrm{z}$ uwagi na fakt, iż wydają się dobrze znane w literaturze przedmiotu, wśród jakże wielu prowadzonych analiz nowoczesności zastanej przez ludzkość od paru już dekad. Umownie wpisują się one w sam tytuł książki Ulricha Becka w teoretyczny i praktyczny system trudnej i niebezpiecznej nowoczesności społeczeństwa ryzyka (por. Tobera, 2000, ss. 6-7). 
W końcu lat osiemdziesiątych ubiegłego stulecia znany socjolog Sławomir Kapralski (1989) podjął się - moim zdaniem bardzo udanej - próby szerszej prezentacji resentymentu publicznego/narodowego w kategoriach stricte socjologicznych interpretacji tego pojęcia, ukazując przy tym podstawowe odmiany zbliżonego, ale jednak innego niż potoczne spojrzenia na zjawisko (Kapralski, 1989, ss. 67-80). Podtrzymując opinię Kapralskiego, nadmieniam, że pomimo różnorodności znaczeniowej tego terminu walory opisowo-eksploracyjne pozostają niezmiennie przydatne w wyjaśnianiu współczesnych zachowań ludzkich, chociażby przez same motywy przejawianej na przykład aprobaty, akceptacji znacznej części społeczeństwa polskiego. W języku potocznym pojęcie resentyment oznacza tyle, co przykrość, uraza, rozżalenie (odczuwane przez dłuższy czas, powracające wspomnienia), zwłaszcza doznawane po wyrządzonych osobie krzywdach, niepowodzeniach we własnej sytuacji egzystencjalnej, a głównie socjalnej ${ }^{12}$. Może wytworzyć się ów stan oczywiście po wstrząsie, urazie psychicznym, spowodowanym zmianą społeczną przez jeden bodziec zewnętrzny lub wiele urazów. Są to stany doznawane i przeżywane wspólnie nie tylko przez jednostki, ale również całe grupy społeczne. Nie stają się przedmiotem debat publicznych i nie inicjują, względnie mobilizują do podjęcia określonych działań intencjonalnie organizujących się w ruchy społeczne, jak to ma miejsce w przypadku traumy/ politraumy. Resentyment, zgodnie z wykładnią Andrzeja Galicy, wywodzi się $\mathrm{z}$ języka francuskiego (ressentiment).

[...] W potocznym języku francuskim słowo to oznacza: po pierwsze utrwalony w naszej psychice powtarzający się nawrót przeżywania określonej reakcji emocjonalnej, wymierzonej przeciwko drugiemu człowiekowi. Emocja ta się pogłębia, poza tym nie jest ona li tylko powrotem w pamięci do jakiegoś zdarzenia, lecz także odżywaniem emocji na nowo, choć z opóźnieniem. Po drugie, należy zwrócić uwagę, że jest to emocja ujemna i kryje w sobie odruch wrogości. Jest więc resentyment urazą, gniewem, który ukształtował się we wnętrzu człowieka, na skutek nieprzyjaznych uczuć. Uraza nie musi w sobie zawierać od razu jakiegoś wrogiego zamiaru. Lecz kiedy taki zamiar się pojawi, może ona stać się dla niego pożywką (http://www.racjonalista.pl/kk.php/s. 4631).

12 Najpopularniejszymi wyrazami bliskoznacznymi do tego słowa zapewne pozostają: niezadowolenie, nieprzychylność, awersja, uprzedzenie, pretensja, niechęć itp. (Słownik wyrazów obcych, 1978, s. 645). 
Myślicielami, którzy wprowadzili do nauk społecznych owo pojęcie, byli Max Weber, Max Scheler oraz Friedrich Nietzche, i sam już ten fakt z natury samego wstępnego oglądu dowodzi, że posługując się psychologią opisową - filozofowie zajęli się również skrupulatnie w XIX i XX wieku doznaniami, jakie przeżywamy, a które tak naprawdę okazują się zwykłymi fenomenami, pojawiającymi się w akcie samego doznania. Niezależnie od tego, czy jego genezę upatrujemy w judaizmie (jak Max Scheler), czy nawiązujemy do Heglowskiej koncepcji upatrującej w nim zapośredniony konkretny resentyment, który posiada bezpośrednie relacje ze strukturą społeczną i określonym światopoglądem filozoficznym, a także religijnym (Max Weber), lub to powracając do historii judaizmu (Friedrich Nietzsche); mówimy o tym samym procesie rozpatrywanym z różnych punktów widzenia. Ów ostatni opiera się „[...] na historii Izraela, by pokazać kształtowanie się systemu wartości tego narodu, co związane jest ostatecznie z osobą Jezusa z Nazaretu. Jest to psychologiczno-filozoficzna rozprawa o rozwoju moralności żydowskiej, narodu, który wypracował sobie bardzo negatywną chęć zemsty, wynikającą z braku właściwych środków (duchowych czy fizycznych), by móc przeciwstawić się swoim adwersarzom. To owa niemożność »właściwej « zemsty, bezsilność w stosunku do wroga - zdaniem Nietzschego - rodzi bunt niewolników, czy »moralność niewolników«.

Niewolnik nie może »wyładować« swojego pragnienia zemsty bezpośrednio, wyrządzając nieprzyjacielowi krzywdę - fizyczną, moralną czy też psychiczną. Tak rodzi się zemsta wyimaginowana, czy odłożona "na później«, którą można by zobrazować zdaniem: "poczekaj no, następnym razem...«" (Galica, 2006, s. 2; Kapralski, 1989, ss. 66-69; i inni). Na doznanie uczucia/ poczucia resentymentu oddziałuje szereg czynników. Narażone są, a więc podatne na ich stymulację, różne grupy społeczne - chociażby starsza generacja w stosunku do młodszej. Zjawisko zaledwie opisane fragmentarycznie polega na odwróceniu porządku wartości. Te tradycyjnie wyższe zdegradowane często zostają do wartości niższych, i odwrotnie. Wytworzenie (ukształtowanie się) takiej właśnie postawy i postrzeganie zewnętrznego świata opartego na złudnych wartościach, specyficznych osądach moralnych, to z jednej strony przejaw poczucia bezradności, a z drugiej wzmacniające je liczne zabiegi propagandowo socjotechniczne, o których mowa była w poprzedniej części opracowania. Parafrazując język państwowego obecnie przekazu, uogólniam, że idzie nowe propagowanie treści, by stać się wreszcie „człowiekiem odrodzonym", interioryzujac wszelkie nadawane partyjne i rzadowe przekazy treściowe. Przekazywana wizja ideału sprawiedliwości społecznej w perspek- 
tywie wykreowania nowego bezustannie korygowanego systemu politycznego, a także moralnego ${ }^{13}$ we współczesnej Polsce prowadzić musi do stałego wzmacniania administracji centralnej, mającej tym samym przewagę również nad innymi formami mobilizacji środowisk lokalnych w społeczeństwie obywatelskim.

Prawdopodobieństwo zagrożenia centralizmem stale wzrasta wówczas, kiedy w danej zbiorowości (casus: naród) pojawia się coraz więcej zwolenników wyznających "politykę bezwzględnej ufności, zaufania i wiary” w stosunku do elit rządzących, przyjmowanej z atencją, bez zrozumienia, po prostu a priori. W takim ładzie społecznym miejsca szczególnie eksponowane zajmować mogą szerokie rzesze ludowe preferujące pospolitą politykę masową o ludycznym charakterze (Śpiewak, 1999, s. 77), ludzi bardzo często nieufnie i demaskatorsko nastawionych do liberalnej demokracji. Jest to zatem zarówno źródło, jak i rezultat tłumionej od wielu lat nienawiści i niezadowolenia, które zawierają wizję nieistniejącego już, ale i opartego na niesprawiedliwości byłego porządku i ładu publicznego. Przebiegał on według logiki myślenia $\mathrm{w}$ bardzo uproszczonej interpretacji, pozostając przeważnie w konfrontacji z niebiańskim dniem sądu ostatecznego nastałym w królestwie Bożym, w świecie - w odczuciu np. osoby głęboko wierzącej - dobroci, dosytu, równości, uczciwości i sprawiedliwości. Jak wspomniano uprzednio, stanowi ów typ idealny zarys/wizję tworzoną przez individum jako universum izulorycznego świata wartości norm oraz ocen etycznych. Stanowić ma rekompensatę za pewną własną niemoc, określam ją mianem samokompensacji.

Jeśli zatem zaistnieje koincydencja opisanych warunków: niespójnej struktury, określonych systemów myślowych i szczegółowego typu codziennych interakcji, to z dużą dozą prawdopodobieństwa można domniemywać, iż działania ludzi mających równe z innymi prawa, lecz faktycznie nierównych innym, wierzących przy tym, że ów stan rzeczy, choć niesprawiedliwy, musi trwać, oraz systematycznie poniżanych $\mathrm{w}$ życiu codziennym, będą sterowane przez resentyment (Kapralski, 1989, s. 76).

13 W Polsce konserwatyści i tradycyjni zwolennicy feudalno-autokratycznego ładu społecznego z reguły są przekonani, że wolno im przygotować listę cnót podstawowych, wśród których pojawić się mogą nowe zasady kształcenia i wychowania, struktury porządku publicznego, a także doboru osób (w oparciu o partyjnie sporządzone kryteria) na kluczowe pozycje w komunitarystycznie sprawowanej władzy (Śpiewak, 1999, s. 72; Szachaj, 2005, ss. 131-135). 
Sprzyjają takiej sytuacji właśnie kody/hasła nadawcy kierowane ku ludności o niższym poziomie wykształcenia, które sprawiają, że socjopsychologicznej zmianie podlegać zaczyna także traktowanie własnej wspólnoty narodowej i reprodukowanie/odtwarzanie tożsamości zbiorowej i indywidualnej przy użyciu określonej mowy/przekazu; jak to jednoznacznie wykazuje Basil Bernstein. Niewykluczone, że następuje spowolnione wygaszanie pewnego okresu historycznego ludzkości. Nastaje nowa cywilizacja, u progu której stoimy i której trendów rozwojowych nie da się jeszcze przewidzieć? Sprawdzają się, tak twierdzą Marcin Król i Anita Miszalska, przenikliwe proroctwa Tocqueville’a na temat bieżącej, otaczającej nas demokracji.

Po pierwsze, że zatriumfuje miernota, która zdominuje wszystko - sferę publiczną i prywatną. Po wtóre, sprawdziła się teza o dewastującym wpływie demokracji na kulturę. Po trzecie wreszcie, siłę swą pokazał samorząd lokalny, potęga wspólnoty lokalnej okazała się większa od wszystkich innych form organizacji życia publicznego (Tocqueville, 1996; Król, 1998; Miszalska, 2000, s. 24).

Niebagatelną rolę odgrywają z całą pewnością emocje i ich rola wiążąca się z racjonalnym bądź irracjonalnym wyborem przedstawionej oferty politycznej. Zmieni się z pewnością (a również za sprawą ogarniającej świat pandemii koronawirusa) cały dotychczasowy kontekst społeczno-cywilizacyjny obowiązujących dotychczas prawideł funkcjonowania ładu społecznego, co może napawać na przyszłość optymizmem. Być może dokonanie wyboru będzie bardziej refleksyjne? Dziś jednak dominuje smętny wizerunek, bowiem, jak sugestywnie trafnie spostrzega Anita Miszalska:

Elementem polskiej kultury politycznej i wielką słabością polskiej demokracji jest deficyt „kapitału społecznego” - brak więzi społecznej, solidarności, zaufania, bezinteresownej pomocy. Jeśli zaś tego nie ma, nie ma też demokratycznej, obywatelskiej wspólnoty, jest wyłącznie zatomizowane społeczeństwo. W Polsce solidarność częściej przybierała wyraz negatywny, to znaczy była wymierzona przeciwko komuś lub czemuś, nie była zaś solidarnością państwowotwórczą, solidarnością wspólnego budowania. Tak było w czasach rozbiorów, okupacji, komunizmu. Diagnoza socjologów jest zgodna: społeczeństwo obywatelskie jest w Polsce słabe. [...] Rozwijające się ruchy społeczne i organizacje pozarządowe są z pewnością krokiem w kierunku wypełnienia „próżni socjologicznej" pozostawionej w spadku przez PRL, ale wciąż pozostaje 
to raczej potrzebą grupy społeczników-hobbystów i nie przekłada się na ugruntowany społeczny obyczaj. Cechą polskiej kultury samoorganizacji społecznej wciąż pozostaje akcyjność i spektakularne zrywy, a nie systematyczne, codzienne kultywowane cnot republikańskich. W codziennych stosunkach międzyludzkich dominuje egoizm, obojętność, nieufność i wewnętrzna wrogość (jej przejawem jest choćby antykomunizm i antyklerykalizm, etniczne resentymenty oraz zdziczenie i brutalizacja zachowań). Prospołeczność zaś przybiera postać „prospołeczności klanowej”, zorientowanej na własną grupę, na „swoich”.

Znamienne, że po 1989 roku niewiele zmieniło się w tradycyjnych postawach Polaków wobec własnego państwa. Wciąż nie jest ono traktowane jako „swoje”, lecz jako zewnętrzna siła, wobec której obywatele czują się wyalienowani i nadal myślą kategoriami „my-oni”. [...] Nasze życie polityczne operuje językiem wrogości, a nie współpracy i kompromisu, pełne jest wzajemnych donosów, oskarżeń, insynuacji, co psychologicznie oddala obywateli od władzy. Opiera się ono na filozofii „korporatyzmu plemiennego” (określenie Miry Marody), pełniąc bowiem funkcje publiczne i realizując jakieś cele zbiorowe myśli się przede wszystkim o korzyściach własnych grup i środowisk - partyjnych, zawodowych, lokalnych itp. „Swoimi” obsadza się wszelkie możliwe stanowiska, „swoim” przydziela się koncesje, „swoi” wygrywają przetargi publiczne itd. W ten sposób tworzy się patologizującą demokrację kultur, prywaty, korupcji, manifestacji, a nie etos obywatelski (Miszalska, 2000, s. 40).

Tkwimy jednak w okresie przejściowym. Obok rysów swoistych i narodowo-mentalnych występują jak zawsze w okresie intensywnej zmiany społecznej wspólne cechy typowe, polegające m.in. na ścieraniu się i przeciwstawianiu elementów starej (tradycyjnej) struktury i próby tworzenia odmiennych sytuacji kreującej (nowoczesne) społeczeństwo. Novum jest/staje się wypadkową przeciwstawnych elementów, nie tylko o obliczu niechęci, animozji, wrogości, ale także zarzewiem potencjalnego konfliktu, który oby jak najprędzej ustabilizował nowy ład społeczny (Dobrowolski, 1973, s. 33; Komandera, 1986, s. 63; Radziewicz-Winnicki, 2008, ss. 267-270).

Wszystko to jednak tworzy na bieżąco rozkojarzenie ogólne postrzegane w kontekście relatywnie długiego dla osobnika okresu stanu permanentnego anomii dzisiejszej Polski. 


\section{Zakończenie}

Artykuł starałem się ograniczyć do ram dotychczasowej znanej teorii Basila Bernsteina, bowiem w moim przekonaniu ta orientacja teoretyczna stanowi nadal wysoki potencjał wyjaśniający socjolingwistyczny mrok naszej podświadomości (a również świadomości), dzięki któremu - pomimo bierności społecznej - narodową rzeczywistość rodzinnego konstruktu społecznego można zrozumieć i przewidywać. Przyjmuję zatem, za Piotrem Sztompką, iż zanim doczekamy się nowych teorii intepretujących jeszcze bardziej wiarygodnie aniżeli dotychczas historyczne doświadczenia przełomu postkomunistycznego na tle światowej globalizacji globu, należy sięgać z pewnością do znanych już teorii istniejących opisujących m.in. kompetencje i niekompetencje cywilizacyjne. Poddając analizie słowotwórcze kody, hasła, wyrażenia i wiążące się z nimi emocje propagowane przez PiS, a często wywoływane wręcz bezpośrednio, usiłowałem przedstawić potencjalną możliwość kontynuowania istniejącej anomii i chaosu publicznego który doprowadzi cały naród do nieobliczalnego konfliktu. Można zaryzykować stwierdzenie o dziennikarsko-eseistycznej interpretacji, iż istnieje wysokie prawdopodobieństwo na poziomie od przeciętnego wyższym, że nastąpią wkrótce szczególne interakcje wynikające ze wzajemnej niezgodności o zdecydowanie opozycyjnym charakterze, które wywołują w dobie kryzysu prawdziwą walkę spoteczna, m.in. starcia uliczne. Kierując się sugestią socjologii historycznej oraz historii wychowania, starałem utrzymać kierunek w zakresie przyjętej strategii i interpretacji wyjaśnień uogólniajacy, jak i partykularyzujacy ${ }^{14}$. Ów sposób interpretacji rodzić może nadzieje, że kontynuowane i przypominane będą nadal podwaliny historycznego, antropologicznego i naukowego wyjaśniania, a przy tym również indywidualnego zrozumienia (percepcji) ze strony odbiorców.

14 Ów pierwszy wynika z logicznych zasad wnioskowania przyczynowego w określonym czasowo i przestrzennie systemie/procesie społecznym w latach 1989-1990 w Polsce. A drugi to wyjaśnienie - jak je określa Ewa Morawska - partykulacyjne wywodzące się z analiz interpretacyjno-konfigurujących, które to zależności pomiędzy wieloma elementami całości traktowane jest nie autonomicznie, lecz w kontekście całości [...] tj. wskazania zespołu czynników przyczyniających się do powstania (trwania zmiany) danej sytuacji historycznej oraz wyjaśnienia ich współoddziaływania uznaje za równoznaczne z rozpoznaniem przyczyn (konsekwencji) owej sytuacji; ma na celu nie uogólnienie, lecz ustalenie warunków specyfiki badanej sytuacji (Morawska, 2002, s. 67). 
W innej potencjalnej perspektywie podmiotowość społeczna - jak twierdzi Bronisław Gołębiowski - może być groźna dla samych nadawców/ kreatorów bez przyswojenia przez nich oczekiwanej przez ekspertów samoświadomości osobowej, tzn. samowiedzy, zdolności do samowychowania i samodyscypliny. W skrajnym przypadku możemy sobie wyobrazić współczesne społeczeństwo polskie, w którym wszyscy zapragną być podmiotami działań innych, przypadkowych postaci, nie potrafiąc kierować nawet samymi sobą (Gołębiowski, 1986, ss. 143-144). Tak więc wątki poruszane powyżej $\mathrm{w}$ obszarze egalitaryzmu społecznego $\mathrm{w}$ powiązaniu $\mathrm{z}$ dystrybutywną sprawiedliwością lub też racjonalnym wyborem polityczno-publicznym na tle obraźliwego i uproszczonego ideologicznego przekazu wiodacej partii politycznej o intencjach socjotechnicznego wpływu we współczesnej Polsce muszą wywołać szereg opinii, przekonań i postaw społecznych, wyrażając przy tym ich propostępowe bądź antyreligijne głęboko niesprzyjające nowoczesności nastawienie, przywołując pamięć o eksperymentalnym i nieudanym monocentrycznym ładzie społecznym ludowego państwa sprzed trzydziestu lat.

Ta stosowana obecnie popkultura polityczna [...] upośledza głębokie procesy psychologiczne, które stanowią podstawę funkcjonowania człowieka, zwłaszcza jego funkcjonowania w kulturze. Nie sprzyja koncentracji i długotrwałej, zogniskowanej uwadze. Faworyzuje zaś elementy typowe dla zachowań istot „zaledwie” świadomych, takie jak: a) analizowanie wydarzeń w oderwaniu od szerszego kontekstu czasowo-przestrzennego; b) natychmiastowe nagradzanie; c) próbuje nieustannie odwracać i zawłaszczać nasza uwagę (co jest wynikiem nieustającej konkurencji medialnej); d) wykształca mechanizmy zbliżone do warunkowania, funkcjonuje dzięki skojarzeniom; e) bazuje bardziej na naturalnych skłonnościach, aniżeli na oczekiwaniach wykształcanych społecznie (specjalizuje się raczej w przełamywaniu społecznych tabu); f) preferuje znacznie szybsze, choć mniej dokładne, strategie analizy - myślenie hasłami, obrazkami; innymi słowy, procesy nielinearne (takie jak dialog, czy praca z tekstem) z reguły są pomijane jako nużące. Odrzuca natomiast to, co typowe dla zachowań podmiotów samoświadomych" szerszy kontekst czasowo-przestrzenno-kulturowy i mniejszą koncentrację na „tu i teraz” możliwość planowania, zakotwiczenie w tradycji kulturowej, wykształcenie oraz internalizację norm, a zarazem większe zorientowanie na cele wspólnoty. Jest egoistyczna wspiera roszczeniowe nastawienie do świata (Kozłowski, 2011, s. 225) 
Starałem się także zaakcentować niezbywalne credo nadal nas obowiązujące, iż rola naukowej wiedzy i wynikającego z niej światopoglądu stanowi zawsze dobro niekwestionowane. Pamiętamy o tej prawdzie z chwilą demaskowania wszelkich działań fałszywych i nierzetelnych, bądź to podważania autonomii samej nauki (Amsterdamski, 1999, ss. 299-300). To zarazem sprzeciw wobec irracjonalnej i nieprawdziwej argumentacji propagandowo-ideowej, a wręcz agitatorskiej, próbującej zdyskredytować wszelki wysiłek intelektualny przeciwstawiającej się logice rozumu, utopii doktrynalnej fantazji i chorobliwemu obłędnemu urojeniu.

\section{Bibliografia}

Archer, M. 2019. Kultura i sprawczość. Miejsce kultury w teorii społecznej.

Warszawa: Narodowe Centrum Kultury.

Bernstein, B. 1980. Socjolingwistyka a społeczne problemy ksztatcenia. W: Głowiński, M. red. Język i społeczeństwo. Warszawa: Wydawnictwo Czytelnik, ss. 83-119.

Bernstein, B. 1971. Class, codes and control. Vol. 1. London: Routledge and Kegan Paul.

Bernstein, B. 1974. Class, codes and control. Vol. 2. London: Routledge and Kegan Paul.

Bernstein, B. 1975. Class, codes and control. Vol. 3. London: Routledge and Kegan Paul.

Bernstein, B. 1990. Odtworzenie kultury. Warszawa: PIW.

Bielecka-Prus, J. 2020. Transmisja kultury w rodzinie $i$ w szkole. Warszawa: PWN.

Bielska, E. 2013. Koncepcja oporu we wspótczesnych naukach spotecznych. Główne problemy, pojęcia, rozstrzygnięcia. Katowice: UŚ.

Bogardus, E.S. 1925. Social distance and its origions. Journal of Applied Sociology. 9, pp. 216-226.

Bokszański, Z., Piotrowski, A. i Ziółkowski, M. 1977. Socjologia języka. Warszawa: Wiedza Powszechna.

Bokszański, Z. i Piotrowski, A. 1990. Wstęp. W: Basil Bernstein: Odtworzenie kultury. Warszawa: PIW, ss. 5-23.

Dobrowolski, K. 1973. Teoria procesów żywiołowych w zarysie. Wrocław: Ossolineum. 
Doliński, D. 2005. Wpływ społeczny. W: Encyklopedia socjologii. Suplement. Warszawa: Oficyna Naukowa, ss. 380-386.

Floud, J. 1978. Functiones, purposes and powers in education. Podano za: Szreter, R.: Landmarks in the institutionalisation of social of education. Educational Review. 32, pp. 290-301.

Gajdzica, A. (2013). Portret zbiorowy nauczycieli aktywnych. Między zmiana a oporem. Cieszyn - Toruń: Wydział Etnologii i Nauk o Edukacji Uniwersytetu Śląskiego, Wydawnictwo Adam Marszałek.

Galica, A. 2006. Nietzsche - Scholar - Resentyment. http://www.racjonalista. pl/kk.php/s.4631 (26.03.2020).

Gołębiowski, B. 1986. Uniwersytety ludowe w perspektywie przemian współczesnej edukacji i kultury. Kultura i Społeczeństwo. 4, ss. 143-159.

Halsey, A.H. (1971). Theoretical advance and empirical challenge. In: Hopper, E. ed. Readings in the theory of educational systems. London: Hutchinson University Library, pp. 262-281.

Kaczyński, J. 2017. Prezes PiS o nowym wielkim ataku nienawiści. Polsat News, 10.05.2017.

Karabel, J. and Halsey, A.H. 1977. Introduction. Educational research: a review and on interpretation. In: Karbel, J. and Halsey, A.H. eds. Power and ideology in education. New York, Oxford: University Press, pp. 1-85.

Kapralski, S. 1989. Resentyment a zmiana społeczna. Studia Socjologiczne. 2, ss. 67-80.

Kłosińska, K. i Rusinek, M. 2019. Dobra zmiana. Czyli jak się rzadzi światem za pomoca słów. Kraków: Społeczny Instytut Wydawniczy Znak.

Komandera, A. 1986. O zastosowaniu pojęć typologicznych w badaniach przeobrażeń wiejskich społeczności. Studia Socjologiczne. 4, ss. 62-122.

Kopaliński, W. 1971. Stownik wyrazów obcych. Warszawa: Wiedza Powszechna.

Kowalski, S. 1990. Krytyka solidarnościowego rozumu. Warszawa: Wydawnictwo PEN-Tezeusz.

Kozłowski, T. 2011. Elementy transmisji prokulturowej w społeczeństwie konsumpcyjnym. Kultura i Społeczeństwo. 2, ss. 209-228.

Król, M. 1998. Demokracja wychowała cyników. Życie, 3-4 października.

Lewowicki, T. 2007a. O tożsamości, kondycji i powinnościach pedagogiki. Warszawa - Radom: Instytut Technologii Eksploatacji - PIB.

Lewowicki, T. 2007b. Problemy ksztatcenia i pracy nauczycieli. Warszawa Radom: Instytut Technologii Eksploatacji - PIB. 
Mariański, M. 1995. Młodzież między tradycją a nowoczesnością. Lublin: Wydawnictwo KUL.

Mikułowski-Pomorski, J. 1995. Ksztattowanie się obrazu Europy w prasie polskiej w latach 1989-1991. Wrocław - Warszawa - Kraków: Ossolineum.

Miszalska, A. 2000. Sytuacja demokracji u schyłku wieku. Kultura i Społeczeństwo. 3, ss. 23-46.

Morawska, E. 2002. Socjologia historyczna. W: Encyklopedia socjologii. T. 4. Warszawa: Oficyna Naukowa, ss. 65-69.

Murawski, K. 1989. Władza: Organizacja i współdziałanie. Studia Socjologiczne. 4, ss. 65-80.

Nowicka, E. 2005. Obcy. W: Encyklopedia socjologii. Suplement. Warszawa: Oficyna Naukowa, ss. 165-170.

Nowosad, I. 2009. Kultura szkoty w rozwoju szkoty. Kraków: Oficyna Wydawnicza „Impuls”.

Olechnicki, K. i Załęcki, K. 1997. Słownik socjologiczny. Toruń: Wydawnictwo Graffiti BC.

Park, Cf. E. 1924. The concept of social distance. Journal of Applied Sociology. 8, pp. 339-344.

Radziewicz-Winnicki, A. 1984. Socjologia wychowania w Wielkiej Brytanii (Narodziny, stan, tendencje rozwojowe). Edukacja. 5, ss. 12-25.

Radziewicz-Winnicki, A. 1985. Z dziejów rozwoju socjologii wychowania w Wielkiej Brytanii (Studium historyczno-porównawcze). Kwartalnik Historii Nauki i Techniki. 2, ss. 337-356.

Radziewicz-Winnicki, A. i Walker, S. 1986. Rozwój Socjologii Wychowania w Polsce i w Zjednoczonym Królestwie Wielkiej Brytanii. Konfrontacje polsko-brytyjskie. W: Radziewicz-Winnicki, A. red. Pedagogika a socjologia wychowania. Katowice: UŚ, ss. 34-65.

Radziewicz-Winnicki, A. 1993. Działania kompensacyjne oraz struktura wiedzy edukacyjnej w teoriach Basila Bernsteina. W: Radziewicz-Winnicki, A. red. Wspótcześni socjologowie o wychowaniu (zarys wybranych koncepcji). Katowice: UŚ, ss. 7-27.

Radziewicz-Winnicki, A. 1998. Tradition and reality in educational ethnography of post - communist Poland. Essays in sociology of education and social pedagogy. Frankfurt Main - Berlin - Bern - New York - Paris Wien: Peter Lang.

Radziewicz-Winnicki, A. 2004. Urbanizacja versus globalizacja. Auxilium Sociale - Wsparcie Społeczne.1, ss. 9-29. 
Radziewicz-Winnicki, A. 2017. Komunitaryzm w percepcji współczesnej pedagogiki i praktyki społecznej. Pedagogika Społeczna, 1, s. 9-28.

Radziewicz-Winnicki, A. 2008. Pedagogika społeczna. Warszawa: WAiP.

Radziewicz-Winnicki, A. i Wilk, T. 2019. Społeczne funkcje narracji w książkach i rozprawach Profesora Jerzego Nikitorowicza / Osobliwości prezentacji i czytelniczej recepcji. W: Sobecki, M., Misiejuk, D., Muszyńska, J. i Bajkowski, T. red. Człowiek. Pogranicze. Wyzwania Humanistycznej Edukacji. Białystok: Wydawnictwo UwB, ss. 53-75.

Rawls, J. (1994). Teorie sprawiedliwości. Warszawa: PWN.

Rogalska-Marasińska, A. 2017. Edukacja międzykulturowa na rzecz zrównoważonego rozwoju. Łódź: UŁ.

Rudzki, J. 1962. „Bild-Zeitung” jako narzędzie kształtowania opinii publicznej i integracji społeczeństwa NRF (październik - grudzień 1961). Studia Socjologiczne. 3, ss. 183-205.

Sawisz, A. 1989. Szkoła a system społeczny. Warszawa: WSiP.

Szachaj, A. 2005. Komunitaryzm. W: Encyklopedia socjologii. Suplement. Warszawa: Oficyna Naukowa, ss. 131-135.

Stownik wyrazów obcych PWN. 1978. Warszawa: PWN.

Szempruch, J. 2010. The school and the teacher in the period of change. Kraków: Oficyna Wydawnicza „Impuls”.

Szempruch, J. 2013. Pedeutologia: Studium teoretyczno-pragmatyczne. Kraków: Oficyna Wydawnicza „Impuls”.

Szempruch, J. 2018. Feeling of professional burnout in teachers of secondary schools. The New Eduational Rewiew. 4 (54), pp. 219-230.

Sztompka, P. 1994. Teorie zmian społecznych a doświadczenia polskiej transformacji. Studia Socjologiczne. 3, ss. 9-35.

Sztompka, P. 1997. Kulturowe imponderabilia szybkich zmian społecznych. Zaufanie, lojalność, solidarność. Studia Socjologiczne. 4, ss. 5-19.

Śliwerski, B. 2015. Edukacja (w) polityce. Polityka (w) edukacji. Kraków: Oficyna Wydawnicza „Impuls”.

Śpiewak, P. 1999. Konserwatyzm. W: Encyklopedia socjologii. T. 2. Warszawa: Oficyna Naukowa, ss. 73-77.

Śliwa, M. 2014. Społeczne i psychologiczne skutki totalitaryzmu. Wrocław: UW.

Tocqueville, A. 1996. O demokracji w Ameryce. T. 2. Kraków: Społeczny Instytut Wydawniczy Znak.

Tobera, P. 2000. Niepokojąca nowoczesność. Kultura i Społeczeństwo. 3, ss. 3-21. 
Wallis, A. 1984. Struktury społeczne wobec urbanizacyjnej hipertrofii. Kultura i Społeczeństwo. 3, ss. 3-8.

Wark, C. and Gallier, J.F. 2007. Emory Bogardus and the Origins of the Social Distance Scale. The American Sociologist. 38, pp. 383-395.

\title{
"Restricted Codes" in Basil Bernstein's theory versus the feeling of social re-sentiment (the perspective of enlightened education presented to public blindness and inaction)
}

\begin{abstract}
The author's considerations concern several relationships in the last period of fundamental changes in Poland. The influence of the press and other media agitation also expressed in a lot of opinions directed to the less educated part of the Polish society ( 44\%) by representatives of the govermental party "Low and Justice" recalls in human consciousness an emotional social resentiment. This is the process of social reception of many media transmissions in the category of electoral campaign's agitation (interventional strategies) on the continuum: personality - perception - emotional susceptibility - political choice. The paper contains the fragment of sociolinguistic theory of Basil Bernstein of language and its influence on the individuum's perception of the reality.
\end{abstract}

Keywords: theory of Basil Bernstein, Basil Bernstein's theory, elaborated and restricted codes, languages transmission, public resentiment, political emotions

Translated by Andrzej Radziewicz-Winnicki 